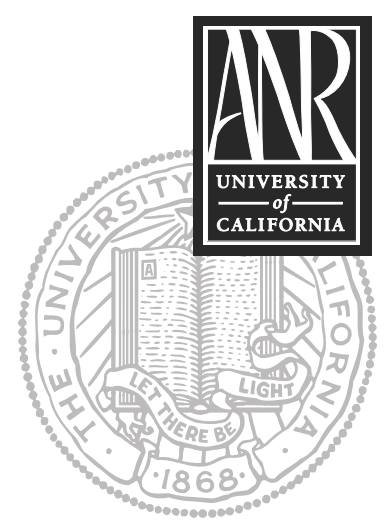

UNIVERSITY OF CALIFORNIA

Division of Agriculture and Natural Resources http://anrcatalog.ucdavis.edu

\title{
FOREST STEWARDSHIP SERIES 2 A Forest Stewardship Framework
}

GREGORY GIUSTI, UCCE Forest Wildland Ecology Advisor, Mendocino County; RICHARD HARRIS, UCCE Forestry Specialist, Department of Environmental Science, Policy, and Management, University of California, Berkeley

B. E. Fernow, chief of the USDA's Division of Forestry in 1894, wrote in that year's Book of Agriculture, "in order to harmonize the requirements of the wood lot from a sylvicultural point of view, and the needs of the farmer for wood supplies, the cutting must follow some systematic plan." This astute statement, written over 100 years ago, still rings true today. In those simpler days, a landowner's primary worries dealt only with the immediate needs of planting, cultivating, and producing a "crop" of trees over time. It is interesting that even with these modest goals, the author spoke eloquently of the need to have a management plan for guidance.

In today's world, landowners need to know many things to be successful forest stewards. It is of the utmost importance to understand the ecological and environmental effects of various management practices. For those seeking economic returns, it is essential to be informed about markets, costs, and regulatory requirements. Landowners today must consider their place in the community and how their activities can influence their neighbors, other species, and other forest users.

Simply stated, there is a great deal more to forest stewardship today than just growing, cutting, and marketing trees. Forest stewards must plan activities well in advance, accurately assess resources, manage potential wildland fuel sources, address erosion and water quality issues, and know how to use sound information to make management decisions. For many California forest landowners, economic returns are incidental or unimportant; they may be more interested in forest restoration or enhancement. Nevertheless, these landowners too must consider the effects of their management (or nonmanagement) actions.

Forestland management decisions are implemented over a long time span, often exceeding an individual's lifetime. The impacts of those decisions affect you and your family as well as your neighbors. These decisions also influence the management of nearby lands and may impact streams and water sources hundreds of miles away. Your decisions have repercussions on wildlife, fire protection, water quality, and scenic values. Even if your decision is to do nothing and let the forest take care of itself, that decision impacts a multitude of resources.

\section{A FOREST IN SPACE AND TIME}

The condition of the forest you own or manage today is largely a consequence of historical land use practices. In all but a small percentage of public lands, forestlands throughout the state have been significantly altered by harvest activities in the relatively recent past.

The society of the indigenous peoples of California before the appearance of Europeans was essentially a subsistence-based culture very different from the modern market-based culture that dominates today. Understanding these societal differences is important if we are to understand how human intervention has impacted forest conditions. Prior to the California Gold Rush, indigenous Californians manipulated 
the forest for food production, shelter, and protection to meet their needs. Though they relied heavily on harvestable products from the forest, in most cases they left the forest structure relatively intact. Hence the extensive presence of "old growth" forests prior to European settlement.

Since the mid-1850s, trees have been harvested and exported to the far reaches of the world to meet the needs of a larger, more mobile and more consumer-driven society. These modern activities, along with the absence of periodic fires, have shaped the structure and composition of the forests we see today. The modern land use practice of cutting and growing trees on a rotational time frame is a relatively new practice in California's forests, and we still have much to learn about its long-term ecological effects.

\section{FORESTRY: A MULTIDISCIPLINARY SCIENCE}

Forestry is commonly defined as the science of developing, caring for, or cultivating forests. In all but a few cases, people in California own and manage native forests; that is, the forests being managed were not artificially planted to produce wood fiber (as are plantations, woodlots, etc.). These forests, however, are often the result of timber harvesting followed by natural regeneration from remaining and surrounding forests.

California's forests are a product of climatic and soil conditions that have evolved over millions of years. The first redwood trees are found in the fossil record 66.4 million years ago. This precursor to modern redwoods was growing in Wyoming! Fossilized pollen deposits show that today's oak woodlands, so widespread across California's landscape, were established just after the last ice age 10,000 years ago.

Caring for and cultivating a forest should be premised on the fundamental principle that not all forests are created equal. In other words, a pine forest has different needs and requirements than a redwood forest or a fir forest or an oak forest. However, in every case, each forest type deserves equal consideration when cultivating its properties so that the intricacies of each forest type can be conserved.

Modern forest management recognizes the importance of applying a multidisciplinary assemblage of technical skills, practical experience, and educated judgment. Whether your goal is to manage your forest for recreational purposes, economic gain, or both, over time you will need to use information from a broad range of sources and disciplines. These include:

- Silviculture: The art of growing and harvesting trees to ensure sustainable production of timber and nontimber resources over time.

- Forest protection: The need to manage pests, pathogens, weeds, and wildland fuels to maintain the overall health and economic and personal values associated with your land.

- Ecology: The science of understanding the relationships between organisms and their environment and how management decisions can influence those relationships.

- Engineering: The physical science important for properly planning and building roads, sizing and placing culverts, and restoring streams.

- Soil science: The understanding of soil protection and conservation measures to avoid compaction and erosion.

- Business administration: Knowledge of how to select a forester and other contractors, as well as how to sell logs, minimize taxes, and conduct other business endeavors.

- Marketing: Ability to identify what you have to market and sell, such as logs, other forest products, or recreational opportunities. 
There is no question that modern management activities can dramatically alter forest conditions, affecting ecological integrity and potentially resulting in long-lasting environmental consequences. In order to get full personal enjoyment and financial returns while still protecting the forest's integrity you will need to continually seek out new information so that your decisions are based on current science and select a registered professional forester (RPF). Selecting a forester is similar to selecting any other professional service provider, whether a physician, attorney, tax consultant, or auto mechanic. You will want to choose someone with whom you are comfortable sharing complex and personal information.

\section{DEFINING FINANCIAL OBJECTIVES}

Do not ask the forest to do something that is beyond its capacity. Forests grow at predictable rates depending on species, soil conditions, weather patterns, and geographic location. Think of your forestland as a bank account with the trees serving as principal and their annual growth as interest. In the simplest terms, if withdrawals (harvests) exceed deposits (growth), over time the account will be liquidated. Developing a financial strategy based on periodic conservative harvests will ensure that the principal will grow over time. For example, if you develop a harvest strategy that is premised on extracting from 25 to 30 percent of growth over any 10-year period, then you can realize a compounding benefit of growing more wood fiber than you are extracting. Over time, this will result in higher volumes of timber per acre being grown in larger trees of higher quality. This strategy will provide far greater financial returns over time than more aggressive harvest schedules that often result in long periods of no harvest activities.

\section{DEFINING ENVIRONMENTAL OBJECTIVES}

The financial objectives established for your forestland will have environmental consequences. A financial strategy based on a conservative, sustainable level of harvest will, over time, heal many of the environmental impacts of past short-term extraction schemes. Aggressive, high-intensity forestry may subject a forest to environmental conditions that are not conducive to maintaining ecological functions, potentially impacting wildlife and fish populations, water quality, and regeneration efforts. A management plan should recognize the inherent conditions and disturbance regimes of your particular forest type so your management actions will be appropriate to your forestland.

\section{WHERE TO START?}

As you can imagine, managing a piece of forest property is a complex and often intimidating task. One starting point all landowners should pursue is a written management plan. This can be as simple as collecting documents such as deeds and receipts along with maps and written notes, or it can be as complex as a detailed prescriptive plan using forest inventory and growth analysis to explore alternative management scenarios. Setting obtainable goals and specific management objectives down on paper helps you create the forest that you desire. A written plan

- documents the information you use to reach your decisions

- allows you to clearly communicate your desires for your property to others, such as your family and land management professionals

- helps demonstrate your commitment to forest management for tax purposes

- helps you prioritize management decisions and turn your objectives into actions

- can help guide your heirs in continuing management of the property 
A key benefit of developing a written forest management plan is that it helps you learn more about your property and its management. Consider developing the plan to be an educational experience. You will learn more about your land-probably quite a lot-and also gain new insights and information you need in order to make informed decisions.

\section{FOR FURTHER INFORMATION}

To order or obtain printed ANR publications and other products, visit the ANR Communication Services online catalog at http://anrcatalog.ucdavis.edu. You can also place orders by mail, phone, or FAX, or request a printed catalog of our products from:

University of California

Agriculture and Natural Resources

Communication Services

6701 San Pablo Avenue, 2nd Floor

Oakland, California 94608-1239

Telephone: (800) 994-8849 or (510) 642-2431

FAX: (510) 643-5470

E-mail inquiries: danrcs@ucdavis.edu

An electronic version of this publication is available on the ANR Communication Services Web site at http://anrcatalog.ucdavis.edu.

Publication 8232

ISBN-13: 978-1-60107-452-2

(C) 2007 by the Regents of the University of California, Division of Agriculture and Natural Resources. All rights reserved.

The University of California prohibits discrimination or harassment of any person on the basis of race, color, national origin, religion, sex, gender identity, pregnancy (including childbirth, and medical conditions related to pregnancy or childbirth), physical or mental disability, medical condition (cancer-related or genetic characteristics), ancestry, marital status, age, sexual orientation, citizenship, or status as a covered veteran (covered veterans are special disabled veterans, recently separated veterans, Vietnam era veterans, or any other veterans who served on active duty during a war or in a campaign or expedition for which a campaign badge has been authorized) in any of its programs or activities. University policy is intended to be consistent with the provisions of applicable State and Federal laws.

Inquiries regarding the University's nondiscrimination policies may be directed to the Affirmative Action/Staff Personnel Services Director, University of California, Agriculture and Natural Resources, 300 Lakeside Drive, 6th Floor, Oakland, CA 94612-3550 (510) 987-0096. For a free catalog of other publications, call (800) 994-8849. For help downloading this publication, call (530) 297-4445.

This publication has been anonymously peer reviewed for technical accuracy by University of California scientists and other qualified professionals. This review process was managed by the ANR Associate Editor for Natural Resources.

pr-12/07-SB/CM 